\title{
MYTH AND POETICS
}

\author{
A series edited by
}

\section{GREgORY NAGY}

Helen of Troy and Her Shameless Phantom

by Norman Austin

Poetry in Speech: Orality and Homeric Discourse

by Egbert J. Bakker

The Craft of Poetic Speech in Ancient Greece

by Claude Calame

translated by Janice Orion

Masks of Dionysus

edited by Thomas W. Carpenter and Christopher A. Faraone

The Odyssey in Athens: Myths of Cultural Origins

by Erwin F. Cook

The Poetics of Supplication: Homer's Iliad and Odyssey

by Kevin Crotty

Poet and Hero in the Persian Book of Kings

by Olga M. Davidson

Gender and Genre in the Folklore of Middle India

by Joyce Burkhalter Flueckiger

The Ravenous Hyenas and the Wounded Sun: Myth and Ritual in Ancient India by Stephanie W. Jamison

Poetry and Prophecy: The Beginnings of a Literary Tradition

edited by James Kugel

The Traffic in Praise: Pindar and the Poetics of Social Economy

by Leslie Kurke

Topographies of Hellenism: Mapping the Homeland

by Artemis Leontis

Epic Singers and Oral Tradition

by Albert Bates Lord

The Singer Resumes the Tale

by Albert Bates Lord, edited by Mary Louise Lord

The Language of Heroes: Speech and Performance in the Iliad by Richard P. Martin 
Heroic Sagas and Ballads

by Stephen A. Mitchell

The Anger of Achilles: Mênis in Greek Epic

by Leonard Muellner

Greek Mythology and Poetics

by Gregory Nagy

$M y$ th and the Polis

edited by Dora C. Pozzi and John M. Wickersham

Knowing Words:Wisdom and Cunning in the Classical Traditions of China and Greece

by Lisa Raphals

Heroic Poets, Poetic Heroes: The Ethnography of Performance in an Arabic Oral Epic Tradition by Dwight Fletcher Reynolds

Homer and the Sacred City

by Stephen Scully

Singers, Heroes, and Gods in the Odyssey

by Charles Segal

The Mute Immortals Speak: Pre-Islamic Poetry and the Poetics of Ritual

by Suzanne Pinckney Stetkevych

Phrasikleia: An Anthropology of Reading in Ancient Greece

by Jesper Svenbro

translated by Janet E. Lloyd

The Jewish Novel in the Ancient World

by Lawrence $\mathrm{M}$. Wills 